Bajopas Volume 2 Number 2 December, 2009

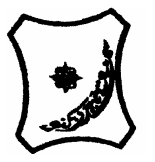

Bayero Journal of Pure and Applied Sciences, 2(2); 44 - 48

Received: February, 2009

Accepted: June, 2009

\title{
EFFECT OF PRE-SOWING HARDENING TREATMENTS USING VARIOUS PLANT GROWTH SUBSTANCES ON COWPEA GERMINATION AND SEEDLING ESTABLISHMENT
}

\author{
Audi, A. H* and Mukhtar, F. B. \\ Department of Biological Sciences, Faculty of Science, Bayero University, PMB 3011, Kano \\ Correspondence Author: audigenesis@daad-alumni.de
}

\begin{abstract}
Seed germination and seedling establishment of two cowpea varieties IT87D-941-1 (IPI) and Kanannado (LPI) were carried out in the laboratory in Kano, Nigeria under the prevailing laboratory conditions of $25 \pm 2^{\circ} \mathrm{C}$ and $45-60 \%$ relative humidity. The cowpea seeds were presoaked in various solutions of $5 \mathrm{ppm}$ and 10ppm Indole acetic acid (IAA), Gibberellic acid (GA $\left.{ }_{3}\right)$ and Ascorbic acid (AA), concentrations respectively. The soaked seeds were air dried for 24hrs and thereafter sown in various flasks containing dried cotton wool. The result of the study showed significant difference in percentage germination among the cowpea varieties and hormone concentrations $(P<0.001)$. Seeds treated with $5 \mathrm{ppm} I A A$ and $G A_{3}$ showed significant increases in percentage germination and seedling growth in the two cowpea varieties. Germination and seedling growth decreased markedly with increasing hormone concentration. Seeds pre-soaked in distilled water responded poorly. Based on these results, 5 ppm concentrations of IAA and $G_{3}$ were found to be the best for enhancing seedling growth in cowpea and it is therefore recommended for cowpea seedling establishment. The result also emphasized that pre-sowing hardening treatment of cowpea seeds in IAA and $G A_{3}$ could significantly enhance their germination and seedling growth. This suggested that hormone treated cowpea seed have the potential of overcoming adverse effect of water stress in tropical Savannah.
\end{abstract}

Keywords: Plant growth substances, Cowpea, Germination, Seedling Establishment

\section{INTRODUCTION}

Cowpea (Vigna unguiculata (L) Walp) (Leguminosae: Papilionoidae) represent the main food legume and a versatile crop in tropical Africa. It is drought tolerant and could produce better growth in warm climates. It is most popular in the semi arid regions of the tropics where other food legumes are available (Singh and Sharma, 1996). The crop has been described as the major source of dietary protein in tropical and subtropical regions of the world especially where animal protein consumptions are low (Opareke et al., 1998). Efforts made to maximize yield, is largely hampered by adverse effect of a biotic stress such as salinity and drought. These effects cause a huge loss due to law yield and failure of the crop to establish in some cases. Alternative approach towards efficient and cost effective means of production of cowpea in the tropical Savannah is very desirable. Pre-sowing hardening seed treatment is an easy, low cost and low risk technique and also an alternative approach recently used to overcome the effect of abiotic stresses in agricultural production. It is found to be efficient in improving seed emergence and growth of crops (Bradford, 1986: Parera and Cantiliffe, 1991). Pre-sowing hardening treatment is a repeated soaking and control seed hydration in solution containing organic or inorganic solute (Heydecker et al., 1973; Khan et al., 1980; Dane berger et al., 1992; Pill and Necker, 2001), followed by redrying that allows pregerminative metabolic activities but prevent radicle emergence (Young et al., 1977; Bradford, 1986; Khan, 1992; Pill, 1994 and Basra et al., 2003). The hardening treatment proved to be better for vigour enhancement than the traditional soaking (Basra, et al., 2005). It was reported clearly that the hardening treatment enhance seeds vigour by protecting structure of the plasma membrane against injury during stress (Bewley and Black, 1982; JunMin et al., 2000). It is a well establish fact that, pre-soaking seeds with optimal concentration of phytohormones enhance their germination, growth and yield of some crop species under condition of environmental stress by increasing nutrient reserves through increased physiological activities and root proliferation (Asana et al., 1955; Dave and Gaur, 1970; Garg and Srivastava, 1970; Singh and Darra, 1971; Darra et al., 1973; Bozeuk, 1981; Risvi, 1994).

Previous studies have also shown that presowing seed treatment in various concentration of Indole acetic acid (Ozturk et al., 1993; Zaidi and Singh, 1993; Hegazi et al., 1995; Kumar and Singh 1996; Gulnaz et al., 1999), Gibberellic acid (Ungar, 1977; Warieng, 1982; Cohn and Castle, 1984; khan and Risvi, 1994; Keely and Fotherringham, 1997; Mella et al., 1997; Radi et al., 2001; Anguish et al., 2001) and Ascorbic acid (Verma and Srivastava, 1998; Roy and Srivastava, 1999; Roy and Srivastava, 2001; Alhakimi and Hamada, 2001) may promote or inhibit seedling growth. However little is emphasized on how plant growth hormones could affect cowpea seed germination and seedlings growth. The main objective was to assess the physiological effect of Indole ${ }_{3}$ acetic acid (IAA), Gibberallic acid $\left(\mathrm{GA}_{3}\right)$ and Ascorbic acid (AA) on germination and seedling growth of cowpea. 


\section{MATERIALS AND METHODS}

The study was carried out in the Physiology Laboratory, Department of Biological Sciences Bayero University Kano, Nigeria. Cowpea seeds used for the experiments were obtained from the International Institute of Agriculture (IITA), Kano Research Station. The cowpea accessions were IT87D-941-1 which is an improved, photo-insensitive variety (IPI). Brown in colour, rough in texture and Kanannado variety, which is local photosensitive (LPI), white in colour and also rough in texture. These seeds were sterilized after weighing using $75 \%$ ethanol in $250 \mathrm{ml}$ conical flask.

\section{Pre-Sowing Hardening Treatments}

Different concentrations of the growth substances prepared in the laboratory were transferred from the reagent bottles into $50 \mathrm{mls}$ conical flasks which were clearly labelled according to the concentration of the growth substances to be used in the soaking treatment. Some quantities $5 \mathrm{ppm}$ and $10 \mathrm{ppm}$ each of Indole acetic acid (IAA), Gibberellic acid $\left(\mathrm{GA}_{3}\right)$ and Ascorbic acid (AA) were used for soaking the seeds separately. There were actually two controls; distilled water treatment and the untreated seeds which were not presoaked before sowing. The seeds were soaked in the various concentrations of the growth substances and the distilled water for a period of an hour after which they were drained using cotton wool and allowed to dry on filter papers for $24 \mathrm{hrs}$ before sowing. The weight of each treated seed variety was taken after drying using a weighing balance. Distilled water was also used for soaking and to also serve as control (Darra et al., 1973) so that the effect of seed pretreatment on plant growth should not be affected by the differences in seed development along with untreated seeds for comparing the effect of various pre-treatments.

\section{Planting of Seeds}

After drying, the seeds were sown on moist filter papers in $9 \mathrm{~cm}$ well labelled Petri dishes. Into each petridish, 10 seeds were sown for each hormone concentration and this was replicated 3-times making a total of 48-samples (Petri dishes). The Petri dishes were covered and left by the window side of the laboratory. The seeds were inspected at interval and moistened regularly with water. Each replicate was weighed after 2 hours, 4hours, 6hours and every 24hours by means of a digital weighing balance to note the weight change. Observation was made daily for 7-days period during which any seeds germinated were recorded. This was maintained for a period of 3weeks after which growth of seedlings (shoot length and root length) was measured using a thread and meter rule. These procedures were repeated three times at intervals to facilitate computation of the recorded data. The experiment was laid out in a completely randomize design. All percentages were transformed prior to analysis. Data obtained were subjected to two ways ANOVA in randomized block design using the Genstat Statistical Software (1995 version). Rate of imbibition was taken as change in fresh weight.

\section{RESULTS}

Seed germination varied significantly among the varieties and hormone concentrations $(P<0.001)$. Percentage germination in the two cowpea varieties increased with increase in number of days after sowing (Table 1). The results showed significant increase in the germination percentage for seeds presoaked in the various hormones when compared with distilled water and the unsoaked seeds that had no treatment. Maximum increase of up to about $90 \%$ and $73 \%$ for IT87D-941-1 and Kanannado presoaked in 5ppm IAA was observed. This was followed by $5 \mathrm{ppm}$ each $\mathrm{GA}_{3}$ and $\mathrm{AA}$ treatment in Kanannado (83 and $77 \%$ ) and IT87D-941-1 (67\% respectively. Lower percentage germination was observed in distilled water treated seeds (50 and 33\%) for IT87D-941-1 and Kanannado respectively, and the least was recorded in the unsoaked seeds (Table 1). Comparison of the treatments shows that $10 \mathrm{ppm} \mathrm{GA}_{3}$ and $\mathrm{AA}$ resulted in significantly $(P<0.001)$ lower percentage germination in IT87D-941-1 (66.6\% and 63.3\%) respectively and in Kanannado (53.3\%).

Tables 2 and 3, shows the rates of imbibition in the two cowpea varieties. There was progressive increase in weight as the number of hours increased from 2 to $168 \mathrm{hrs}$ in both the treated seeds and the controls. The rate of imbibition varied significantly $(P<0.001)$ in the two cowpea varieties as a result of the hormone treatments. Greater imbibition was recorded in the hormone treated seeds of the two varieties by $168 \mathrm{hrs}$ after sowing compared with the distilled water treated and the untreated seeds (Tables 2 and 3 ). Maximum weight change was however observed in seeds presoaked in $5 \mathrm{ppm}$ IAA followed by $5 \mathrm{ppm} \mathrm{GA}$ and $\mathrm{AA}$ in IT87D-941-1(9.0, 8.4 and $8.0 \mathrm{~g}$ ) and Kanannado (12.4, 10.5 and $10.0 \mathrm{~g}$ ) respectively. Least weight change was observed in the controls in both cowpea varieties. Water uptake was initially rapid at $2 \mathrm{hrs}$ of imbibition then it slowed down with a short lag phase between 2-6hrs but picks up again at accelerating phase from $6-72 \mathrm{hrs}$ in IT87D-941-1. In Kanannado, the lag phase lasted from 6-24hrs while the second phase of rapid growth was from 24-72hrs (Tables 2and 3).

Root and shoot lengths also varied with different hormone concentration $(P<0.001)$ as presented in Table 4. Significant increase in lengths of root and shoot were observed in the hormone treated seeds when compared with the controls (distilled water and untreated seeds) the exception was the root lengths of Kanannado pre-soaked in $10 \mathrm{ppmAA}(3.8 \mathrm{~cm})$ which did not differ significantly from distilled water treated seeds $(3.7 \mathrm{~cm})$. Root lengths were markedly higher in seeds presoaked in lower hormone concentration (5ppm $\mathrm{GA}_{3}$ and $5 \mathrm{ppm}$ IAA respectively). The variety, IT87D941-1 had great root lengths $(8.9$ and $8.0 \mathrm{~cm})$ than Kanannado $(6.8$ and $5.7 \mathrm{~cm})$. These were induced by $5 \mathrm{ppm} \mathrm{GA}$, 5ppm IAA (Table. 4). Conversely, the shoot length was greater in the seeds presoaked in higher concentrations, which are 10ppm IAA and 10ppm $\mathrm{GA}_{3}$. The longest shoot was recorded in IT87D-941-1 seeds germinated following $10 \mathrm{ppm}$ IAA and $\mathrm{GA}_{3}$ pre-sowing treatments with 14.8 and $16.2 \mathrm{~cm}$ respectively. 
Bajopas Volume 2 Number 2 December, 2009

Table 1. Percentage Germination for the 2-Cowpea Varieties (IT87D-941-1 and Kanannado) presoaked in various Concentrations of IAA, GA ${ }_{3}$ and $A A$

\begin{tabular}{lllllllll}
\hline & \multicolumn{3}{c}{$\begin{array}{c}\text { Percentage germination/day (\%) } \\
\text { IT87D-941-1 }\end{array}$} & \multicolumn{3}{c}{ Kanannado } \\
\hline Hormone hardening treatment & $\mathbf{1}$ & $\mathbf{2}$ & $\mathbf{3}$ & $\mathbf{4}$ & $\mathbf{1}$ & $\mathbf{2}$ & $\mathbf{3}$ & $\mathbf{4}$ \\
\hline 5ppm IAA & 33.3 & 56.6 & 80.0 & 90.0 & 20.0 & 40.0 & 63.3 & 73.3 \\
10ppm IAA & 26.6 & 46.6 & 66.6 & 76.6 & 16.6 & 30.0 & 50.0 & 56.6 \\
$5 \mathrm{ppm} \mathrm{GA}$ & 36.6 & 50.0 & 70.0 & 83.3 & 16.6 & 36.6 & 60.0 & 66.6 \\
10ppm GA & 23.3 & 43.3 & 63.3 & 66.6 & 13.3 & 26.6 & 50.0 & 53.3 \\
5ppm AA & 26.6 & 46.6 & 56.6 & 76.6 & 16.6 & 23.3 & 53.3 & 66.6 \\
10ppm AA & 23.3 & 40.0 & 50.0 & 63.3 & 13.3 & 16.6 & 43.3 & 53.3 \\
Dist $\mathrm{H}_{2} \mathrm{O}$ & 16.6 & 30.0 & 43.3 & 54.0 & 10.0 & 13.3 & 33.3 & 43.3 \\
Untreated & 10.0 & 16.6 & 30.0 & 46.6 & 6.6 & 16.6 & 30.0 & 36.0 \\
Mean X & 24.54 & 41.21 & 57.47 & 69.62 & 14.12 & 25.37 & 47.90 & 56.12 \\
LSD (5\%) & 3.918 & 5.777 & 8.237 & 6.953 & 2.015 & 3.837 & 4.339 & 4.546 \\
\hline
\end{tabular}

Table 2. Rate of Imbibition in Germinating Cowpea Seed (Kanannado Variety) as affected by different Hormone Concentrations of IAA, $\mathrm{GA}_{3}$ and AA

\section{Weight change/hrs}

\begin{tabular}{lccccccccccc} 
Hormone hardening treatment & $\mathbf{O h r s}$ & $\mathbf{2 h r}$ & $\mathbf{4}$ & $\mathbf{6}$ & $\mathbf{2 4}$ & $\mathbf{4 8}$ & $\mathbf{7 2}$ & $\mathbf{9 6}$ & $\mathbf{1 2 0}$ & $\mathbf{1 4 4}$ & $\mathbf{1 6 8}$ \\
\hline 5ppm IAA & 2.0 & 4.5 & 4.8 & 5.2 & 5.6 & 9.2 & 11.0 & 12.0 & 12.2 & 12.4 & 12.4 \\
10ppm IAA & 2.0 & 4.6 & 4.9 & 5.4 & 6.4 & 8.8 & 10.0 & 10.4 & 10.5 & 10.5 & 10.6 \\
$5 \mathrm{ppm} \mathrm{GA}$ & 2.0 & 4.7 & 4.9 & 5.2 & 6.0 & 8.2 & 9.3 & 9.3 & 10.1 & 10.3 & 10.5 \\
$10 \mathrm{ppm} \mathrm{GA}$ & 2.0 & 4.5 & 4.7 & 5.0 & 6.0 & 8.2 & 9.1 & 9.1 & 9.7 & 9.8 & 9.8 \\
$5 \mathrm{ppmAA}$ & 2.0 & 4.6 & 4.9 & 5.2 & 6.0 & 8.2 & 9.3 & 9.3 & 9.9 & 9.9 & 10.0 \\
$10 \mathrm{ppm} \mathrm{AA}$ & 2.0 & 4.0 & 4.3 & 4.6 & 5.6 & 7.4 & 8.3 & 8.3 & 8.8 & 8.9 & 9.2 \\
Dist $\mathrm{H}_{2} \mathrm{O}$ & 2.0 & 4.4 & 4.6 & 4.9 & 5.2 & 6.2 & 7.4 & 7.4 & 8.2 & 8.2 & 8.3 \\
Untreated & 2.0 & 4.4 & 4.5 & 4.7 & 5.3 & 6.0 & 6.3 & 6.3 & 6.5 & 6.5 & 6.8 \\
Mean & 2.0 & 4.46 & 4.70 & 5.02 & 5.76 & 7.77 & 8.83 & 9.01 & 9.48 & 9.56 & 9.70 \\
LSD (5\%) & NS & NS & NS & NS & 0.112 & 0.900 & 0.402 & 0.477 & 0.480 & 0.453 & 0.454 \\
\hline
\end{tabular}

Table 3. Rate of Imbibition in Germinating Cowpea Seed (IT87D-941-1 Variety) as affected by different Hormone Concentrations of IAA, GA 3 and AA

Weight change/hrs

\begin{tabular}{lcllllllllll}
$\begin{array}{l}\text { Hormone hardening } \\
\text { treatment }\end{array}$ & $\mathbf{0 h r s}$ & $\mathbf{2 h r}$ & $\mathbf{4}$ & $\mathbf{6}$ & $\mathbf{2 4}$ & $\mathbf{4 8}$ & $\mathbf{7 2}$ & $\mathbf{9 6}$ & $\mathbf{1 2 0}$ & $\mathbf{1 4 4}$ & $\mathbf{1 6 8}$ \\
\hline 5ppm IAA & 2.0 & 4.5 & 4.6 & 4.8 & 5.8 & 7.2 & 8.2 & 8.2 & 8.7 & 8.9 & 9.0 \\
10ppm IAA & 2.0 & 3.9 & 4.0 & 4.1 & 5.0 & 6.0 & 6.9 & 7.3 & 7.5 & 7.5 & 7.5 \\
5ppm GA & 2.0 & 3.9 & 4.2 & 4.3 & 5.0 & 6.5 & 7.6 & 8.1 & 8.2 & 8.2 & 8.4 \\
10ppm GA & 2.0 & 3.5 & 3.7 & 3.8 & 4.4 & 5.8 & 6.8 & 7.3 & 7.4 & 7.4 & 7.5 \\
5ppmAA & 2.0 & 3.8 & 3.9 & 4.0 & 5.0 & 6.2 & 7.0 & 7.6 & 7.8 & 7.8 & 8.0 \\
10ppm AA & 2.0 & 3.4 & 3.5 & 3.7 & 4.8 & 5.6 & 6.8 & 7.0 & 7.0 & 7.0 & 7.1 \\
Dist $\mathrm{H}_{2} \mathrm{O}$ & 2.0 & 3.0 & 3.2 & 3.4 & 4.6 & 5.4 & 6.2 & 6.6 & 6.6 & 6.7 & 7.0 \\
Untreated & 2.0 & 2.6 & 3.0 & 3.2 & 4.4 & 5.2 & 6.0 & 6.4 & 6.6 & 6.7 & 6.8 \\
Mean & 2.0 & 3.57 & 3.76 & 3.91 & 4.87 & 5.98 & 6.93 & 7.31 & 7.47 & 7.52 & 7.66 \\
LSD (5\%) & NS & 0.160 & 0.143 & 0.138 & 0.123 & 0.76 & 0.192 & 0.176 & 0.203 & 0.207 & 0.206 \\
\hline
\end{tabular}

Table 4. Mean Length of Root and Shoot $(\mathrm{cm})$ of the Cowpea Varieties IT87D- 941-1 and Kanannado Presoaked in Various Hormone Concentrations taken at 7- Days after Sowing

\begin{tabular}{|c|c|c|c|c|}
\hline \multirow[b]{2}{*}{ Hormone hardening treatment } & \multicolumn{2}{|l|}{ Root length } & \multicolumn{2}{|l|}{ Shoot length } \\
\hline & IT87D-941-1 & Kanannado & IT87D-941-1 & Kanannado \\
\hline $5 p p m$ IAA & 8.0 & 6.8 & 6.2 & 11.2 \\
\hline 10ppm IAA & 6.6 & 4.7 & 8.0 & 14.8 \\
\hline $5 p p m \mathrm{GA}_{3}$ & 8.9 & 5.7 & 7.2 & 13.8 \\
\hline $10 p p m \mathrm{GA}_{3}$ & 7.8 & 5.5 & 8.5 & 16.2 \\
\hline 5ppmAA & 6.5 & 5.4 & 6.2 & 11.0 \\
\hline 10ppm AA & 5.3 & 3.8 & 6.5 & 12.5 \\
\hline Dist $\mathrm{H}_{2} \mathrm{O}$ & 3.5 & 3.7 & 5.2 & 9.2 \\
\hline Untreated & 2.0 & 2.4 & 3.5 & 7.4 \\
\hline Mean & 6.07 & 4.75 & 6.41 & 12.01 \\
\hline LSD (5\%) & 1.926 & 1.138 & 1.293 & 2.390 \\
\hline
\end{tabular}

Data are means of 3-determinations $(n=3)$. 
Bajopas Volume 2 Number 2 December, 2009

\section{DISCUSSION}

Seeds showed variable responses to presowing hardening treatments with respect to germination. Soaking in $5 \mathrm{ppm}$ IAA $\mathrm{GA}_{3}$ and $\mathrm{AA}$ produced higher germination percentages than seeds soaked in $10 \mathrm{ppm}$ hormone concentrations. Pretreatment in $5 \mathrm{pmm}$ IAA gave maximum seed germination on the $4^{\text {th }}$ day (96hrs of imbibition) with about $90 \%$ and $73 \%$ for IT87D-941-1 and Kanannado varieties respectively. This conforms with the work of Ventura (1987) who reported that IAA stimulates germination of Lupinus albus at concentration of less than $10 \mathrm{mMl}$.rate of germination in terms of radicle emergence was faster in IT87D-941-1 compared with Kanannado (Table 1). The delayed radicle emergence observed in Kanannado could be attributed to differences in the composition of seed cotyledons and hardness of seed testa (Ashram and Iram, 2002; Mukhtar and Alhassan, 2006). Seeds presoaked in distilled water had higher percentage germination than the unsoaked seeds. This pattern agrees with the reports of Rehman et al. (1998) and Kamboh et al. (2000) that presoaking treatment in distilled water exhibit considerable effectiveness on germination and later growth in different plant species under saline and non-saline conditions. Another observation also reported the ineffectiveness of presoaking in distilled water to improve germination and growth in wheat (Chaudhuri and Weibe, 1968) and Kentucky blue grass (Poa pratensis) (Pill and Necker, 2001).

Rate of imbibition in terms of change in fresh weight as presented in tables 2 and 3 showed that the pre-sowing soaking treatments increased the rate of imbibition particularly in the seeds presoaked in lower concentration (5ppm) of IAA, $\mathrm{GA}_{3}$ and AA by $168 \mathrm{hrs}$. This result can be related with the findings of Northern (1972); Salisbury and Ross (1997) that hormones generally decrease viscosity of cytoplasm and increase diffusion of water into the cell. Not only decreasing the viscosity of the cytoplasm, the hormones may induce growth by production of substances within the endosperm prior to radicle emergence, which may as well increase the osmotic potential of the cell. This observation could be related with the work of Dias et al. (1993) who reported that growth of embryo increases the osmotic potential thereby increasing water uptake into the cell. Water uptake was initially rapid up to $2 \mathrm{hrs}$ of imbibition prior to radicle emergence but slowed down with a short and steady lag phase as it picked up again at accelerating rate subsequent to radicle emergence from 6 and 24hrs in IT87D-941-1 and Kanannado varieties respectively. The initial rapid uptake of water may be due to the low level of moisture content in the seeds and as water enters the cells, the osmotic potential of the cell is raised and this causes water to enter until the cells become fully turgid (Taiz and Zeiger, 2002). The slow water absorption after the first $2 \mathrm{hrs}$ may be associated

\section{REFERENCES}

Al-Hakimi, A. M. A. and Hamad, A. M. (2001). Counteraction of salinity stress on wheat plants by grain soaking in Ascorbic acid, thiamine or sodium salicylate. Plant Biology, 44:253-261.

Angrish,R.., Kumar, B and Datta, K. S.(2001). Effects of Gibberellic acid and Kinetin on nitrogen content and nitrate reductase activity in wheat under saline conditions. Indian journal of plant physiology, 6: 172177. with the growth of radicle within the seed coat and as the radicle emerged water was absorbed at an accelerating rate thus marking the second phase of rapid water uptake (Taiz and Zeiger, 2002). In Kanannado variety, the lag phase was observed to be longer from 2 hrs up to about 24hrs of imbibition before it picked up again. Hence it can be deduced that rate of imbibition was faster in IT87D-941-1 indicating that, the seed reached saturation stage and became turgid earlier than the Kanannado variety, prior to radicle emergence (Tables, 2and 3). Generally growth response of the two cowpea varieties (IT87D-941-1 and Kanannado) with respect to the presowing-hardening treatments in various growth hormones show variable growth pattern at different stages of their development (germination, shoot and root growth). Root lengths in the two varieties increased with decrease in the hormone levels whereas shoot lengths increased as the hormone concentrations increased. This observation conforms with the findings of Singh (1996); Gulnaz et al. (1999); Khan et al. (2002) that, the quantitative and qualitative responses of plants to different hormones may differ considerably at different plant growth stage. The variety, IT87D-941-1 had the greatest root length than Kanannado. These were induced by $5 \mathrm{ppm} \mathrm{GA}_{3}$, $5 \mathrm{ppm}$ IAA while higher concentrations (10ppm) of the hormones enhance longer shoot growth in Kanannado (Table 4).

The production of high root in plant raised from seeds treated with these hormones suggests that the rate of absorption of available nutrients might have significantly been enhanced. Darra et al. (1977) suggested that plant hormones increase the rate of absorption of water and available nutrients thereby resulting in better growth. The hormones might also have substantially enhanced cell enlargement and rapid increase in cell division as suggested by (Magome, 2004). The development of cowpea presoaked in Ascorbic acid (AA) was observed to be consistently lower when compared with that of Indole acetic acid (IAA) and $\mathrm{GA}_{3}$ treated cowpeas.

\section{CONCLUSION}

The findings of this study revealed that, cowpea germination and early seedling growth were promoted by pre-sowing hardening treatments in IAA and $\mathrm{GA}_{3}$. The lower concentration of these hormones (5ppm) was found to be more effective in inducing germination imbibition and root development of the two cowpea varieties whereas $10 \mathrm{ppm} \mathrm{GA}_{3}$ stimulated greater shoot growth of the seedlings.

\section{Acknowledgement}

The authors acknowledge the effort of International Institute of Agriculture (IITA) for supplying the cowpea seeds used for this study. We also recognize the effort of Mr. Hakeem (IITA) for statistical advice.

Asana, R. D., Mani,V. S. and Prakash, V. (1985). Effect of auxins on growth and yield of wheat. Plant physiology, $8: 279-287$

Ashraf, M. and Iram, A. (2002). Optimization and influence of seed priming with salt of potassium or Calcium in two spring wheat cultivars differing in salt tolerance at the initial growth stages. Agrochemica, 46:47-55.

Basra S. M. A, Farooq M, Tabassum, R. (2005). Physiological and biochemical aspects of seed vigor enhancement treatments in fine rice (Oryza sativa L.). Seed Science \& Technology, 3:29-33. 


\section{Bajopas Volume 2 Number 2 December, 2009}

Bewley, J. D. and Black, M. (1982). Physiology and biochemistry of seeds in relation to germination, Vol. 2. Springer, Berlin, P. 375.

Bozeuk, S. (1981). Effect of Kinetin and Salinity on germination of tomato, Berley and cotton seeds. Annal of Botany, 48:81-84.

Bradford, K. J. (1986). Manipulation of seed water relations via osmo-priming to improve germination under stress conditions. Hort. Sci. 21:1105-1112.

Chaudhuri, M., and Weibe, H. H. (1968). Influence of Calcium pretreatments on wheat germination on saline media. Plant soil, 18:208-216.

Cohn, M. A. and Castle, L (1984). Dormancy in red rice IV. Plant Physiology, 60:552-556.

Danneberger, T. K., McDonalds, M. B., Geron, C. A. and Kumar. (1992). Rate of germination and seedling growth of perennial Ryegrass seeds following osmo conditioning. Horticultural Science, 27:28-30.

Darra, B. L., Seith, S. P., Singh, H. and Mendiratta, R. S. (1973). Effects of hormone directed presoaking emergence and growth of osmotically stressed wheat (Triticum aestivum $\mathrm{L}$ ) seeds. Agronomy journal, 65:299-295.

Dave, I. C. and Gaur, B. K. (1970). Effect of pre-sowing treatment with $\mathrm{GA}_{3}$ and Ascorbic acid on growth and development of Barley. Plant Physiology.13:76-85.

Dias,P., Wilson, K.A and Tan-Wilsson, A.L. (1993). Immunocytochemical analysis of proteolysis in germinating Soybean. Photochemistry, 33:961-968.

Gulnaz, A., Iqbal, J., Farooq, S. and Azam, F. (1999). Seed treatment with growth regulators for crop productivity and salinity tolerance in wheat (Triticum aestivum L). Plant soil, 210:209-217.

Garg, O. K. and Srivastava, M. P. (1970). Yield response of I.R-8 to presowing chemical treatment. Proc. $58^{\text {th }}$ session of Indian Science Congress, part. 3, No.86.

Hegazi, A.M., El-Gaaly, F.M. and El-Din, N.M.N. (1995). Effect of some growth regulators on yield response and yield components of wheat grown under saline conditions. Annal of Agricultural Science, 33:709-717.

Heydecker, W., Higgins, J. and Gulliver, R.L. (1973). Accelerated germination by osmotic seed treatment. Nature, 246:42-44.

JunMin, H., Xiaoping, S. and Jian, Z. (2000). Mitigative effects of hydration-dehydration treatments on salt stress induced injury to tomato seed germination. Deta.Hort.Sinica. 27:123-126.

Kamboh, M. A., Oki, Y. and Adachi, T. (2000). Effect of presowing seed treatments on germination and early seedling growth of wheat varieties under saline conditions. Soil Science and plant Nutrition, 46: 249-255.

Keely, J. E., and Fortheringham, J. (1997). Chemical mechanism of Breaking Dormancy. Seed Science Research, 5:75-80.

Khan, A. A. (1992). Preplant physiolocal conditioning. Hort Review, 13:131-181.

Khan, A. A., Maguire, J.D., Abawi, G.S and Ilya, S. (1992). Matriconditioning of vegetable seeds to improve stand establishment in early field planting. Journal of American Soc.Hort.Sci, 117:41-47

Khan, M. A and Rizvi, Y. (1994). Effect of salinity, temperature and growth regulators on the germination and early seedling growth of Atriplex griffithii var. Stocksii. Canadian journal of Botany, 72:475-479.

Kumar, A., Taylor, M.A., Arif, S.A.M and Davies, H.V. (1996). Potato plant expressing antisense and sense S-adenosyl methionine decarboxylase (SAMDC) transgenes show altered levels of polyamines and ethylene: antisense plant display abnormal phenotype. Plant Journal, 9:147-158.

Magome, H., Yamaguchi, S. Hanada, A., Kamiya, Y. And Odadoi, K. (2004).Dwarf and delayed flowering of Arabidopsis mutant defiecient in gibberellin biosynthesis because of over expression of a putative $\mathrm{AP}_{2}$ transcription factor. Plant journal, 37:720-729.
Mella, R. A, Dahal, P., Yang, H., and Bradford, K. J. (1997). Quantification of $\mathrm{GA}_{3}$ regulated in RNA abundance in Tomato seeds using tissue printing. In Ruthland ed., Encyclopaedia of Plant Physiology. 292-295.

Mukhtar, F.B. and Alhassan, S.(2006). Effect of seed weight and coat on water imbibition and germination of cowpea (Vigna unguiculata (L) Walp). Nigerian Journal of Botany, 19:1:147-155.

Northern H.T (1947). Relation of dissociation of Cellular Protein by Auxin to growth. Journal of Experimental Botany, 103: 668-683.

Opareke A.M, Dike M.C. and Onu, I. (1998). Evaluation of seed and leaf powder of Neem (Azadirachta indica A. Juss) and pirimiphos-methyl for control of Callosobruchus maculatus (F.) in stored cowpea. Entomological Society of Nigeria. Occasional publication. 31: 237-242.

Ozturk, M., Gemici, M., Yilmazer, C and Ozdemir, F. (1993). Alleviation of salinity stress by $\mathrm{GA}_{3}$, Kinetin and IAA, on seed germination of Brassica campestris L. Doga. Turk. Botanik. Dergisi, 17:47-52.

Parera, C. A., and Cantliffe, D. J. (1991). Improved germination and modified imbibition of shrunken- sweet Corn by seed disinfection and solid matrix priming. Journal of American Horticultural Science, 116:942-945.

Pill, W. G. (1994). Low water potential and presowing germination treatments to improve seed quality. In: Basra, A.S. (ed), Seed quality: Basic mechanisms and Agricultural implications. Haworth press. Birmingham, New york. pp: 319-359.

Pill, W. G. and Necker, A. D. (2001). The effect of seed treatment on germination and establishment of Kentucky blue grass (Poa pretenses L.). Seed science and Technology, 29:65-72.

Radi, A. F, Shaddad, M. A. K., El-Enany, A. E. and Omran, F. M. (2001). Interactive effect of plant hormones and Salinity on growth and some metabolite of wheat seedlings. In: plant nutrition: food security and sustainability of agro ecosystem through basic and applied research. $14^{\text {th }}$ Int. plant nutrition. Colloquium Hanover, Germany, pp.436-437.

Rehman, S., Harris, P. J. C., Bourne,W. F.(1998). Effects of presowing treatment with Calcium salts or water on germination and salt tolerance of Acacia seeds. Journal of Plant Nutrition, 21: 277-285.

Roy, N. K. and Srivastava, A. K. (1999). Effect of presoaking seed treatment on germination and amylase activity of wheat (Triticum aestivum L.) under salt stress condition. Rachis, 18: 46-51

Roy, N. K. and Srisvastava, A. K. (2001). Effect of salt stress on seedling growth and carbohydrate content in wheat. Indian journal of plant physiology, 6:212-215.

Salisbury, F.B and Ross, C.W (1992). Plant Physiology. (4th Edn). Belmont: Wadsworth pp. 357-548

Singh, H and Darra, B. L. (1971). Influence of presoaking of seeds with Gibberellic acid and Indole acetic acid on growth and yield attributes of wheat (Triticum aestivum L.) under high salinity sodium absorption ratio and boron levels. Indian Journal of Agricultural Sciences, 41:998-1003.

Singh, B.B and Sharma, B. (1996). Restructuring cowpea for higher yield. Indian journal of Genetics, 56:389-405.

Still D.W and Bradford K. J. (1997). Endo D-mannase activity from individual tomato endosperm in relations to germination. Annual review Plant Physiology, 113: 13-20.

Taiz, L. and Zieger, E. (2002). Plant physiology ( $3^{\text {rd }}$ ed). Sinauuer Associates, Inc. USA. pp. 463-475.

Ventura F. (1987). Effect of IAA seed soaking on germination of Lupinus albus. Journal of Experimental Botany, 106:279284.

Verma, J. and Srisvastava, A. K. (1998). Physiologic basis of salt stress resistance in Pigeon pea (Cajanus cajan L.)-II. Presowing seed soaking treatment in regulating early seedling metabolism during seed germination. Plant physiology and Biochemistry, 25:89-94. 